Article

\title{
Speed and Blood Parameters Differ between Arabian and Žemaitukai Horses during Endurance Racing
}

\author{
Indrè Poškienè ${ }^{1, * \mathbb{D}}$, Renata Gruodytè ${ }^{1}$, Jurgita Autukaitè ${ }^{1}$, Vida Juozaitienè ${ }^{2} \mathbb{D}$ and Ramūnas Antanaitis ${ }^{1} \mathbb{D}$ \\ 1 Large Animal Clinic, Veterinary Academy, Lithuanian University of Health Sciences, Tilžès St. 18, \\ LT-47181 Kaunas, Lithuania; renata.gruodyte@lsmuni.lt (R.G.); jurgita.autukaite@lsmuni.lt (J.A.); \\ ramunas.antanaitis@lsmuni.lt (R.A.) \\ 2 Department of Animal Breeding, Veterinary Academy, Lithuanian University of Health Sciences, Tilžès St. 18, \\ LT-47181 Kaunas, Lithuania; vida.juozaitiene@1smuni.lt \\ * Correspondence: indre.poskiene@lsmuni.lt; Tel.: +37-067596602
}

check for

updates

Citation: Poškienè, I.; Gruodytè, R.; Autukaitè, J.; Juozaitienè, V.;

Antanaitis, R. Speed and Blood

Parameters Differ between Arabian and Žemaitukai Horses during Endurance Racing. Animals 2021, 11, 995. https://doi.org/10.3390/ ani11040995

Academic Editors: Mandy Paterson and Jane M. Williams

Received: 5 March 2021

Accepted: 29 March 2021

Published: 1 April 2021

Publisher's Note: MDPI stays neutral with regard to jurisdictional claims in published maps and institutional affiliations.

Copyright: (c) 2021 by the authors. Licensee MDPI, Basel, Switzerland. This article is an open access article distributed under the terms and conditions of the Creative Commons Attribution (CC BY) license (https:/ / creativecommons.org/licenses/by/ $4.0 /)$.
Simple Summary: Limited information exists on the physiological changes that occur in the horses competing in endurance races. The objective was to provide the initial data describing changes in laboratory measurements of the horses competing in endurance races under temperate conditions and to compare the data between the Arabian horses, which are one of the most popular horse breeds in the world, and a Lithuanian horse breed-Žemaitukai. The study was carried out on 112 horses. Blood samples were collected before and after an endurance race. The Arabian horses were faster compared to the local breed (Žemaitukai). The study showed significant changes in horse blood gasometrical and biochemical indicators.

Abstract: Fédération Equestre Internationale (FEI) has described equine endurance racing as the second largest discipline in the world, above which is only show jumping. The Žemaitukai is an ancient indigenous Lithuanian horse breed known since the 6th or 7th century. The Arabian horse breed is one of the oldest human-developed horse breeds in the world. Compared with other race horse breeds, the muscle tissue of Arabian horses is characterized by significant differences in structure-a predominance of oxidative fiber type I is observed in Arabians, making them the prevailing breed in endurance racing. The Arabian horses are recognized as the leading breed in endurance competitions. Speed, pace, and total time in the race strategy have been extensively studied in human sports, and in contrast, this strategy appears to have been virtually ignored in equestrian sport, despite the potential for contributing to performance optimization. In relation to speed and total time in the race, there are limited data on postrace physical, biochemical, and blood gas parameters of endurance horses. Thus, this study was carried out to investigate the effects of speed on the blood parameters of the Arabian and Žemaitukai horses during an endurance race. Blood samples were taken before and immediately after the exercise. Biochemical and blood gas indicators were analyzed. The study showed significant increases in mean blood gasometrical indicators, such as partial carbon dioxide pressure (8.09-15.18\%, $p<0.001)$; base excess in the extracellular fluid $(14.01 \%, p<0.001$ in the Arabian horses and $172.01 \%$ in the Žemaitukai breed, $p=0.006)$; decreases of the blood electrolyte ionized calcium $(4.38-8.72 \%, p<0.001)$ and the hematocrit and hemoglobin values $(20.05-20.12 \%, p<0.001$ in the Arabian horses and 6.22-6.23\% in the Žemaitukai breed, $p=0.003-0.004)$; and decreases in the base excess in the blood values $(29.24-39.38 \%, p<0.001)$ and lactate $(13.45-31.97 \%, p<0.001)$ in the blood of both breeds in the post-competition horses. Significant increases after competition were determined for the values of creatinine $(21.34-30.82 \%$, $p=0.001-0.004)$, total bilirubin (50.84-56.24\%, $\mathrm{PH}<0.001)$, and albumin $(2.63-4.48 \%, p=0.048-0.001)$ for both breeds. For the faster Arabian horse breed, recovering after racing took half the time that the local Žemaitukai breed did.

Keywords: exercise; horse; endurance; pace; horse breed 


\section{Introduction}

Fédération Equestre Internationale (FEI) has described equine endurance racing as the second largest discipline in the world, above which is only show jumping [1]. Endurance races are described as long-distance competitions $(40-160 \mathrm{~km})$ that are organized into loops, which are arranged over variable terrain, and as a rule, these competitions are completed in one day. In endurance competitions, horse and rider combinations are required to complete the racecourse in good condition, aiming to win [2]. Endurance can be described as an exercise performed at a moderate speed whilst covering a long distance [3]. A horse is an interesting physiological model in this context, because different breeds can be used in all types of physical exercise. For example, the Arabian breed is recognized as well adapted to endurance racing, because the Arabian horses are able to run at an average speed of $20 \mathrm{~km} / \mathrm{h}$ or greater for up to $160 \mathrm{~km}$ (in bouts of 30-40 km) [4]. This level of performance is based on aerobic metabolism, adaptation of the cardiorespiratory system, effective body heat dissipation, and maintenance of homeostasis. The Arabian horse breed is one of the world's oldest breeds. This breed is distinguished by its natural beauty, graceful movement, and athletic endurance. Since Arabian horses originated from the Middle East, they feature the unique ability to thrive in a hot, dry environment [5]. The standard height of the Arabian horse is from 145 to $155 \mathrm{~cm}$ (standing) [6]. The standard weight is between 360 and $450 \mathrm{~kg}$; chest girth $-113.2 \mathrm{~cm}$; body length $-145 \mathrm{~cm}$; cannon bone girth$18.5 \mathrm{~cm}$. Compared with other race horse breeds, the muscle tissue of Arabian horses is characterized by significant differences in structure-the predominance of oxidative fiber type I is observed in Arabians, [7,8]. In an Arabian horse's muscle, the higher proportion of oxidative type I fibers (characterized by a low glycogen content and high triglyceride storage capability) results in a greater use of fat for energy [9]. Due to their exceptional qualities, Arabian horses have been extensively used for over 100 years by horse breeders for the improving of other horse breeds [10]. Arabian horses are often used not only for refinement of other horse breeds, but also for their endurance abilities [11]. The studies of the phenotypic traits of the Žemaitukai showed the average body measurements were: wither height $-133.6 \mathrm{~cm}$; chest girth $-173.2 \mathrm{~cm}$ [12]; body length $-142.2 \mathrm{~cm}$; cannon bone girth $-17.7 \mathrm{~cm}$; weight, $360-420 \mathrm{~kg}$ [13]. The Žemaitukai is a pony by height and type [14]. However, the wide chest, high indices of extension, and massiveness indicate that these horses might have substantial draughting power. Due to thin, strong legs, a low bony index, round hips, a wide trot, good jumping technique, energetic temperament, and mobility, the Žemaitukai horses are considered as very suitable for quick trotting and jumping. Thanks to the aforementioned qualities, the Žemaitukai breed is highly valued and used as a versatile horse breed [13]. Based on the results obtained in our last study, it was stated that the horses of the Žemaitukai breed are suitable for endurance competing [15]. To maximize performance during a race, an athlete has to regulate speed over the entire course of a race. The distribution of energy expenditure during the race is defined as "pacing strategy." Pacing strategy is considered to be a key factor determining overall performance in endurance racing. It is considered that the best strategy in a race is maintaining an even pace, and sometimes gradual declining in speed [16]. The aim of every athlete is to reach a certain distance in the shortest time possible [17]. In endurance athletes, an increased aerobic capacity allows skeletal muscle to metabolize more fat (use energy from fatty acids), while at the same time using carbohydrates as an energy source [18]. An aerobic conditioning program in endurance-type athletes induces an increase in the activity of oxidative metabolism and a decrease in anaerobic metabolism. The adaptive response to exercise is associated with changes in gene expression, metabolism, muscle cell cycle progression, and protein homeostasis. However, the exact mechanisms that occur in equine muscles during exercise related to skeletal muscle endurance in high-intensity training are not well understood [19]. Extensive studies of speed, pace, and total time in racing strategy have been carried out in human sports, whereas in equestrian sport, pacing strategy has been practically ignored, although it is one of the key factors to be analyzed when seeking to optimize horse performance [10]. As regards speed, data on postrace physical, biochemical, 
and blood gas parameters of endurance horses are limited. Therefore, the aim of this study was to investigate the impacts of breed on speed and the blood parameters of the Arabian and Žemaitukai horses during an endurance race.

\section{Materials and Methods}

\subsection{Location, Animals, and Experimental Design}

The research was carried out in accordance within the provisions of the Law of the Republic of Lithuania-order number 8-500 on the protection, keeping and use of animals, of 6 November 1997 (the Official Gazette "Valstybès žinios" number 108-6595, dated 28 November 1997), order number 4-361 of 31 December 1998 of the State Veterinary Service of the Republic of Lithuania on breeding, care, transportation of laboratory animals, and order number 4 of 18 January 1999 of the State Veterinary Service of the Republic of Lithuania on the use of laboratory animals for scientific tests. The study approval number was PK012868. The study was conducted on 60 (27 female and 33 male) clinically healthy Arabian horses and 52 (34 female and 18 male) clinically healthy Žemaitukai horses at six endurance competitions (45 km races) in Lithuania and at the Lithuanian University of Health Sciences Veterinary Academy. All horses were $10 \pm 4$ years old, with an average body weight of $408 \pm 41 \mathrm{~kg}$. The horses were transported from different locations, having been delivered to the competitions at least two hours prior to their first veterinary examinations. Veterinary inspections were carried out according to FEI regulations. After each loop of the races, all competing horses underwent veterinary inspections, and the physical parameters of each horse were recorded. All horses successfully passed veterinary inspections, which were performed prior to the start of the race, during the race, and after the race. For a horse to be considered fit enough to continue the event, its HR must be below $65 \mathrm{bpm}$ within $20 \mathrm{~min}$ of arrival. The criterion for inclusion of horses was successful completion of the race, and only the finishers were included in the further research. All horses were trained for endurance racing and had participated in similar competitions before; however, such factors as the degree of competition experience, the number of competition kilometers completed, and the number of successful races over the recent period were different for each animal. All researched horses were dewormed and vaccinated at a similar time and were not receiving any medications and/or suffering from any infections in the preceding three weeks. All animals were housed in a similar environment and fed a similar diet with adequate mineral and vitamin supplementation; the amounts of salt and water were not limited in the diet.

\subsection{Analytical Procedures}

Blood samples were taken from each animal by applying the technique of jugular venipuncture with $1.6 \mathrm{~mL}$ heparinized vacutainer blood collection tubes for blood gas (Terumo Europe, Belgium) and a $5.0 \mathrm{~mL}$ tube without anticoagulant for serum biochemistry (Terumo Europe, Belgium), 30 min before the start and no later than 30 min after the finish. None of the horses showed stress during the blood sampling, which was carried out in less than $30 \mathrm{~s}$ for each sample. The samples were taken immediately after the first and last veterinary inspections; then they were identified and stored in an ice bath for a maximum period of $30 \mathrm{~min}$ until processing. Using EPOC blood gas analyzers (EPOC, Canada, Ottawa), the following indices were analyzed: hydrogen potential $(\mathrm{pH})$, partial carbon dioxide pressure $\left(\mathrm{pCO}_{2}, \mathrm{kPa}\right)$, partial oxygen pressure $\left(\mathrm{pO}_{2}, \mathrm{kPa}\right)$, base excess in the blood $(\mathrm{BE}, \mathrm{mmol} / \mathrm{L})$, base excess in the extracellular fluid $(\mathrm{BE}$ ecf $\mathrm{mmol} / \mathrm{L})$, bicarbonate $\left(\mathrm{HCO}_{3}\right.$, $\mathrm{mmol} / \mathrm{L})$, oxygen saturation $\left(\mathrm{sO}_{2}, \%\right)$, total carbon dioxide in the blood $\left(\mathrm{tCO}_{2}, \mathrm{mmol} / \mathrm{L}\right)$, hematocrit $(\mathrm{HCT}, \mathrm{L} / \mathrm{L})$, hemoglobin concentration $(\mathrm{Hgb}, \mathrm{mmol} / \mathrm{L})$, glucose $(\mathrm{Glu}, \mathrm{mmol} / \mathrm{L})$, sodium $\left(\mathrm{Na}^{+}, \mathrm{mmol} / \mathrm{L}\right)$, potassium $\left(\mathrm{K}^{+}, \mathrm{mmol} / \mathrm{L}\right)$, calcium $\left(\mathrm{Ca}^{++}, \mathrm{mmol} / \mathrm{L}\right)$, and lactate (Lac, mmol/L).

Serum urea (Urea, mmol/L), glucose (Glu, mmol/L), aspartate aminotransferase (AST, U / L 1), iron (Fe, umol/L), creatinine (CREA, $\mathrm{mol} / \mathrm{L})$, magnesium $(\mathrm{Mg}, \mathrm{mmol} / \mathrm{L})$, total protein $(\mathrm{TP}, \mathrm{g} / \mathrm{L})$, total bilirubin $(\mathrm{TB}, \mu \mathrm{mol} / \mathrm{L} 1)$, albumin $(\mathrm{ALB}, \mathrm{g} / \mathrm{L})$, cuprum $(\mathrm{Cu}$, 
umol/L), zinc (Zn, umol/L), and gamma-glutamyl transferase (GGT, U/L) were measured using an automated analyzer, Hitachi 705 (Hitachi, Japan).

Horse speed and recovery time data were taken from the electronic time-keeping system (ECR v.7.01 Systems, Kaunas, Lithuania) designed for endurance events. Speed data were calculated by dividing the length of the course by the time taken for the horse to complete the course (subtracting hold times). Recovery time is the time that horse spends in the recovery area after crossing the end line of a loop until it crosses the line into the vetting area to be presented for its horse inspection.

The races were held in Lithuania, in accordance with the FEI rules. The competitions were carried out on variable terrain with some muddy and some firm areas, and with slight elevation changes $( \pm 300 \mathrm{~m})$. The environmental conditions during the competitions varied, with the mean temperature being $22.5^{\circ} \mathrm{C}$ (within the range of $12.50-26.5{ }^{\circ} \mathrm{C}$ ) and the mean relative humidity being $73.20 \%$ (within the range of $52-96 \%$ ). For a horse to be considered fit enough to continue the event, its HR must be below $65 \mathrm{bpm}$ within 20 min of arrival.

\subsection{Data Analysis and Statistics}

The data were analyzed using the IBM SPSS Statistics v20.5 for Windows. The distributions of the evaluated traits were used to carry out the assessment according to the Kolmogorov-Smirnov test. The mean (M) value and standard error of the mean (SE) were calculated. To compare blood parameters before and after competition, a paired $t$-test was used; to compare the differences between the breeds before and after competition, the Student's $t$-test for independent samples was employed. The relationships between speed and recovery time and the blood parameters of a horse were assessed using the Spearman method. The results were considered to be significant at $p<0.05$.

\section{Results}

3.1. The Indices of Biochemical Parameters of the Arabian and Žemaitukai Horses before and after Competition

The analysis of biochemical parameters (Table 1) showed significant increases in the values of CREA (21.34-30.82\%, $p=0.001-0.004)$, TB (50.84-56.24\%, $p<0.001)$, and ALB (2.63-4.48\%, $p=0.048-0.001)$ after competition in both breeds.

Before and after competition, significantly higher levels of Fe $(p=0.001$ and $p<0.001)$, CREA $(p<0.001)$, TP and TB $(p=0.023$ and $p<0.001)$, and ALB $(p<0.001)$ were observed in the Arabian horses compared to those in the Žemaitukai breed, for which higher AST $(p<0.001), \mathrm{Cu}(p=0.002$ and $p<0.001)$, and GGT $(p<0.001)$ were found.

\subsection{The Indices of Acid-Base Balance in the Arabian and Žemaitukai Horses before and after Competition}

The study showed significant decreases in mean blood gasometrical indicators, such as $\mathrm{pCO}_{2}(8.09-15.18 \%, p<0.001)$ and BE (efc) $(14.01 \%, p<0.001$ in the Arabian horses and $172.01 \%$ in the Žemaitukai breed, $p=0.006)$ and in the blood electrolyte $\mathrm{Ca}++(4.38-8.72 \%$, $p<0.001)$; and there were increases in HCT and $\mathrm{Hgb}(20.05-20.12 \%, p<0.001$ in the Arabian horses and 6.22-6.23\% in the Žemaitukai breed, $p=0.003-0.004)$, BE (b) (29.24$39.38 \%, p<0.001)$, and Lac $(13.45-31.97 \%, p<0.001)$ in the blood of both breeds in the post-competition horses compared to those measured before competition (Table 2). 
Table 1. The indices of minerals, trace elements, and biochemical parameters in the blood of the Arabian and Žemaitukai horses before and after competition.

\begin{tabular}{|c|c|c|c|c|c|c|c|c|c|c|}
\hline \multirow{2}{*}{$\begin{array}{c}\text { Blood } \\
\text { Parameter }\end{array}$} & \multirow{2}{*}{ Breed } & \multicolumn{3}{|c|}{ Pre-Race } & \multicolumn{3}{|c|}{ Post-Race } & \multicolumn{2}{|c|}{$\begin{array}{c}\text { Changes } \\
\text { (Pre-Race-Postrace) }\end{array}$} & \multirow[t]{2}{*}{ Normal Ranges [20] } \\
\hline & & $\mathbf{M}$ & SE & $p$ & $\mathbf{M}$ & SE & $p$ & Difference (\%) & $p$ & \\
\hline \multirow{2}{*}{ Urea $\mathrm{mmol} / \mathrm{L}$} & Arabian & 6.06 & 0.181 & \multirow{2}{*}{$<0.001$} & 7.29 & 0.311 & \multirow{2}{*}{0.675} & 20.30 & $<0.001$ & \multirow{2}{*}{$2.9-9.6$} \\
\hline & Žemaitukai & 7.05 & 0.181 & & 7.11 & 0.311 & & 0.85 & 0.802 & \\
\hline \multirow{2}{*}{ AST U/L } & Arabian & 301.02 & 12.403 & \multirow{2}{*}{$<0.001$} & 336.93 & 11.862 & \multirow{2}{*}{$<0.001$} & 11.93 & $<0.001$ & \multirow{2}{*}{$205-555$} \\
\hline & Žemaitukai & 434.36 & 12.403 & & 410.09 & 11.862 & & -5.59 & 0.027 & \\
\hline \multirow{2}{*}{ Fe umol/L } & Arabian & 31.34 & 0.849 & \multirow{2}{*}{$<0.001$} & 32.99 & 0.920 & \multirow{2}{*}{$<0.001$} & 5.25 & 0.127 & \multirow{2}{*}{$20-45$} \\
\hline & Žemaitukai & 27.52 & 0.849 & & 25.60 & 0.920 & & -7.00 & 0.002 & \\
\hline CREA & Arabian & 133.00 & 2.539 & \multirow{2}{*}{$<0.001$} & 161.38 & 3.012 & \multirow{2}{*}{$<0.001$} & 21.34 & 0.001 & \multirow{2}{*}{$53.1-159.2$} \\
\hline$\mu \mathrm{mol} / \mathrm{L}$ & Žemaitukai & 107.77 & 2.539 & & 144.15 & 3.012 & & 30.82 & 0.004 & \\
\hline \multirow{2}{*}{$\mathrm{Mg} \mathrm{mmol} / \mathrm{L}$} & Arabian & 0.75 & 0.031 & \multirow{2}{*}{0.336} & 1.42 & 0.248 & \multirow{2}{*}{0.048} & 89.33 & 0.058 & \multirow{2}{*}{$0.6-1.7$} \\
\hline & Žemaitukai & 0.71 & 0.031 & & 0.72 & 0.248 & & 1.41 & 0.892 & \\
\hline anorg $\mathrm{P}$ & Arabian & 1.03 & 0.250 & \multirow{2}{*}{0.994} & 1.05 & 0.249 & \multirow[t]{2}{*}{0.958} & -1.28 & 0.006 & \multirow{2}{*}{$0.8-1.3$} \\
\hline $\mathrm{mmol} / \mathrm{L}$ & Žemaitukai & 1.04 & 0.250 & & 1.03 & 0.249 & & 0.85 & 0.492 & \\
\hline Total Ca & Arabian & 0.67 & 0.036 & \multirow[t]{2}{*}{$<0.001$} & 0.67 & 0.030 & \multirow[t]{2}{*}{$<0.001$} & 0.00 & 0.953 & $0.59-0.74$ \\
\hline $\mathrm{mmol} / \mathrm{L}$ & Zemaitukai & 0.76 & 0.036 & & 0.76 & 0.030 & & 0.00 & 0.874 & \\
\hline $\mathrm{TP} \mathrm{g} / \mathrm{L}$ & Arabian & 78.77 & 0.870 & & 83.62 & 1.098 & & 6.16 & $<0.001$ & \\
\hline $11 \mathrm{~g} / \mathrm{L}$ & Žemaitukai & 75.93 & 0.870 & 0.023 & 75.63 & 1.098 & $<0.001$ & -0.40 & 0.643 & $56-76$ \\
\hline TB (bilirub) & Arabian & 31.61 & 1.467 & & 47.68 & 2.095 & & 50.84 & $<0.001$ & \\
\hline$\mu \mathrm{mol} / \mathrm{L}$ & Žemaitukai & 15.95 & 1.467 & $<0.001$ & 24.92 & 2.095 & $<0.001$ & 56.24 & $<0.001$ & $25-42$ \\
\hline ALB $g / L$ & Arabian & 41.28 & 0.336 & & 43.13 & 0.417 & & 4.48 & 0.001 & \\
\hline ALD g/L & Žemaitukai & 36.93 & 0.336 & $<0.001$ & 37.90 & 0.417 & $<0.001$ & 2.63 & 0.048 & $26-41$ \\
\hline Cuumol/L & Arabian & 10.40 & 1.141 & 0.002 & 10.91 & 1.428 & & 4.92 & 0.177 & \\
\hline Cu umol/L & Žemaitukai & 12.61 & 1.141 & 0.002 & 13.41 & 1.428 & 0.001 & 6.39 & 0.122 & $7.9-39.5$ \\
\hline & Arabian & 26.99 & 0.817 & & 28.07 & 0.683 & & 3.98 & 0.112 & \\
\hline Zn umol/L & Žemaitukai & 28.64 & 0.817 & 0.010 & 27.62 & 0.683 & 0.230 & -3.56 & 0.001 & $12-4 b$ \\
\hline GGTU/I & Arabian & 17.18 & 2.328 & $<0.001$ & 16.70 & 2.390 & $<0001$ & -2.79 & 0.353 & $6-32$ \\
\hline GGI U/L & Žemaitukai & 34.13 & 2.328 & $<0.001$ & 32.70 & 2.390 & $<0.001$ & -4.19 & $<0.001$ & $0-32$ \\
\hline
\end{tabular}

$\mathrm{M}$-mean; $p$-calculated probability; SE—standard error of the mean; Urea-serum urea; AST—aspartate aminotransferase; Fe-iron; CREA—creatinine; Ca—calcium; Mg—-magnesium; TP—-total protein; TB—-total bilirubin; ALB—albumin; Cu- cuprum; Zn—zinc; GGT_ gamma-glutamyl transferase; ND—no data.

Table 2. The indices of electrolyte and acid-base balance in the Arabian and Žemaitukai horses before and after competition.

\begin{tabular}{|c|c|c|c|c|c|c|c|c|c|c|}
\hline \multirow{2}{*}{$\begin{array}{c}\text { Blood } \\
\text { Parameter }\end{array}$} & \multirow[t]{2}{*}{ Breed } & \multicolumn{3}{|c|}{ Pre-Race } & \multicolumn{3}{|c|}{ Post-Race } & \multicolumn{2}{|c|}{$\begin{array}{c}\text { Changes } \\
\text { (Pre-Race-Postrace) }\end{array}$} & \multirow[t]{2}{*}{$\begin{array}{c}\text { Normal Ranges } \\
\text { of Venous } \\
\text { Blood }[21,22]\end{array}$} \\
\hline & & $\mathbf{M}$ & SE & $p$ & $\mathbf{M}$ & SE & $p$ & Difference $(\%)$ & $p$ & \\
\hline \multirow{2}{*}{$\mathrm{pH}$} & Arabian & 7.45 & 0.005 & \multirow{2}{*}{$<0.001$} & 7.51 & 0.005 & \multirow{2}{*}{$<0.001$} & 0.81 & $<0.001$ & \multirow{2}{*}{$7.36-7.43$} \\
\hline & Žemaitukai & 7.49 & 0.007 & & 7.53 & 0.007 & & 0.53 & $<0.001$ & \\
\hline \multirow{2}{*}{$\mathrm{pCO}_{2} \mathrm{kPa}$} & Arabian & 5.34 & 0.094 & \multirow{2}{*}{$<0.001$} & 4.53 & 0.076 & \multirow{2}{*}{$<0.001$} & -15.18 & $<0.001$ & \multirow{2}{*}{$5.06-6.39$} \\
\hline & Žemaitukai & 4.75 & 0.116 & & 4.36 & 0.094 & & -8.09 & $<0.001$ & \\
\hline \multirow{2}{*}{$\mathrm{pO}_{2} \mathrm{kPa}$} & Arabian & 4.91 & 0.342 & \multirow{2}{*}{0.016} & 4.65 & 0.121 & \multirow{2}{*}{0.016} & -5.29 & 0.721 & \multirow{2}{*}{$4.8-6.13$} \\
\hline & Žemaitukai & 6.59 & 0.660 & & 5.39 & 0.386 & & -18.13 & 0.037 & \\
\hline \multirow{2}{*}{$\begin{array}{c}\mathrm{HCO}_{3} \\
\mathrm{mmol} / \mathrm{L}\end{array}$} & Arabian & 27.66 & 0.311 & \multirow{2}{*}{0.032} & 27.92 & 0.413 & \multirow{2}{*}{0.032} & 0.94 & 0.615 & \multirow{2}{*}{$22-29$} \\
\hline & Žemaitukai & 26.58 & 0.384 & & 26.89 & 0.510 & & 1.17 & 0.452 & \\
\hline \multirow{2}{*}{$\begin{array}{l}\mathrm{BE}(\mathrm{efc}) \\
\mathrm{mmol} / \mathrm{L}\end{array}$} & Arabian & 3.64 & 0.295 & \multirow{2}{*}{0.333} & 4.15 & 1.090 & \multirow{2}{*}{0.333} & 14.01 & $<0.001$ & \multirow{2}{*}{$0-5$} \\
\hline & Žemaitukai & 3.18 & 0.364 & & 8.65 & 1.348 & & 172.01 & 0.006 & \\
\hline \multirow{2}{*}{$\mathrm{sO}_{2} \%$} & Arabian & 75.24 & 0.544 & \multirow{2}{*}{0.001} & 75.99 & 0.618 & \multirow{2}{*}{0.001} & 0.99 & 0.320 & \multirow{2}{*}{$70-75$} \\
\hline & Žemaitukai & 78.23 & 0.673 & & 77.24 & 0.764 & & -1.26 & 0.085 & \\
\hline \multirow{2}{*}{$\begin{array}{c}\mathrm{Na}^{+} \\
\mathrm{mmol} / \mathrm{L}\end{array}$} & Arabian & 139.69 & 0.254 & \multirow{2}{*}{0.539} & 139.23 & 0.209 & \multirow{2}{*}{0.539} & -0.33 & 0.057 & \multirow{2}{*}{$136-142$} \\
\hline & Žemaitukai & 139.94 & 0.314 & & 137.76 & 0.259 & & -1.56 & $<0.001$ & \\
\hline & Arabian & 3.54 & 0.048 & & 3.28 & 0.053 & & -7.34 & $<0.001$ & \\
\hline $\mathrm{K} \mathrm{mmol} / \mathrm{L}$ & Žemaitukai & 3.65 & 0.059 & 0.158 & 3.58 & 0.065 & 0.158 & -1.92 & 0.577 & $2.20-4.60$ \\
\hline $\mathrm{Ca}^{++}$ & Arabian & 1.49 & 0.010 & & 1.36 & 0.011 & & -8.72 & $<0.001$ & \\
\hline $\mathrm{mmol} / \mathrm{L}$ & Žemaitukai & 1.37 & 0.013 & $<0.001$ & 1.31 & 0.014 & $<0.001$ & -4.38 & $<0.001$ & $1.25-1.75$ \\
\hline
\end{tabular}


Table 2. Cont.

\begin{tabular}{|c|c|c|c|c|c|c|c|c|c|c|}
\hline \multirow{2}{*}{$\begin{array}{l}\text { Blood } \\
\text { Parameter }\end{array}$} & \multirow[t]{2}{*}{ Breed } & \multicolumn{3}{|c|}{ Pre-Race } & \multicolumn{3}{|c|}{ Post-Race } & \multicolumn{2}{|c|}{$\begin{array}{c}\text { Changes } \\
\text { (Pre-Race-Postrace) }\end{array}$} & \multirow[t]{2}{*}{$\begin{array}{c}\text { Normal Ranges } \\
\text { of Venous } \\
\text { Blood [21,22] }\end{array}$} \\
\hline & & $\mathbf{M}$ & SE & $p$ & $\mathbf{M}$ & SE & $p$ & Difference (\%) & $p$ & \\
\hline \multirow{2}{*}{$\underset{\mathrm{tCO}}{\mathrm{mmol}_{2} / \mathrm{L}}$} & Arabian & 28.88 & 0.329 & \multirow{2}{*}{0.026} & 28.94 & 0.379 & \multirow{2}{*}{0.026} & 0.21 & 0.892 & \multirow{2}{*}{$22-33$} \\
\hline & Žemaitukai & 27.69 & 0.406 & & 27.93 & 0.469 & & 0.87 & 0.376 & \\
\hline \multirow{2}{*}{$\mathrm{HCT}$ L/L } & Arabian & 0.37 & 0.069 & \multirow{2}{*}{0.062} & 0.44 & 0.059 & \multirow{2}{*}{0.062} & 20.12 & $<0.001$ & \multirow{2}{*}{$30-45$} \\
\hline & Žemaitukai & 0.35 & 0.085 & & 0.37 & 0.074 & & 6.23 & 0.003 & \\
\hline \multirow{2}{*}{$\begin{array}{c}\mathrm{Hgb} \\
\mathrm{mmol} / \mathrm{L}\end{array}$} & Arabian & 7.83 & 0.140 & \multirow{2}{*}{0.054} & 9.4 & 0.130 & \multirow{2}{*}{0.054} & 20.05 & $<0.001$ & \multirow{2}{*}{$6.21-9.31$} \\
\hline & Žemaitukai & 7.38 & 0.187 & & 7.84 & 0.155 & & 6.22 & 0.004 & \\
\hline \multirow{2}{*}{$\mathrm{BE} \mathrm{mmol} / \mathrm{L}$} & Arabian & 3.42 & 0.248 & \multirow{2}{*}{0.586} & 4.42 & 0.157 & \multirow{2}{*}{0.586} & 29.24 & $<0.001$ & \multirow{2}{*}{$0-5$} \\
\hline & Žemaitukai & 3.20 & 0.307 & & 4.46 & 0.194 & & 39.38 & $<0.001$ & \\
\hline \multirow{2}{*}{$\begin{array}{c}\text { Glu } \\
\mathrm{mmol} / \mathrm{L}\end{array}$} & Arabian & 5.80 & 0.116 & \multirow{2}{*}{0.004} & 6.09 & 0.159 & \multirow{2}{*}{0.004} & 5.00 & 0.056 & \multirow{2}{*}{$3.4-7.4$} \\
\hline & Žemaitukai & 5.26 & 0.143 & & 5.85 & 0.196 & & 11.22 & 0.001 & \\
\hline \multirow{2}{*}{$\begin{array}{c}\mathrm{Lac} \\
\mathrm{mmol} / \mathrm{L}\end{array}$} & Arabian & 1.47 & 0.098 & \multirow{2}{*}{0.121} & 1.94 & 0.116 & \multirow{2}{*}{0.121} & 31.97 & $<0.001$ & \multirow{2}{*}{$<2.5$} \\
\hline & Žemaitukai & 1.71 & 0.121 & & 1.94 & 0.143 & & 13.45 & $<0.001$ & \\
\hline
\end{tabular}

$\mathrm{M}-$ mean; $p$-calculated probability; $\mathrm{SE}$-standard error of the mean; $\mathrm{pH}$-hydrogen potential; $\mathrm{pCO}_{2}$ - partial carbon dioxide pressure; $\mathrm{pO}_{2}$ - partial oxygen pressure; $\mathrm{BE}$ - base excess in the blood; $\mathrm{BE}$ (efc)—base excess in the extracellular fluid; $\mathrm{HCO}_{3}$ - bicarbonate; $\mathrm{sO}_{2}$ oxygen saturation; $\mathrm{tCO}_{2}$ - total carbon dioxide in the blood; $\mathrm{HCT}$-hematocrit; $\mathrm{Hgb}$-hemoglobin concentration; $\mathrm{Glu}$-glucose; $\mathrm{Na}^{+}$sodium; $\mathrm{K}^{+}$— potassium; $\mathrm{Ca}^{++}$—ionized calcium; Lac—lactate; $\mathrm{ND} —$ no data.

\subsection{Speed and Recovery Time by Breed}

This section describes the speed and recovery time after competition for the Arabian and Žemaitukai horses, and the relationships between speed and blood indices. The study showed that based on electronic time-keeping system data, for the faster Arabian horse breed, recovery time was twice as fast, compared to the local Žemaitukai breed $(p<0.001)$ (Table 3).

Table 3. Speed and recovery time by breed after $45 \mathrm{~km}$ ride.

\begin{tabular}{ccccc}
\hline Indicator & Breed & $\boldsymbol{n}$ & $\mathbf{M}$ & SE \\
\hline Speed km/h & Arabian & 52 & 15.030 & 0.195 \\
Total time & Žemaitukai & 60 & $14.039^{* * *}$ & 0.181 \\
(hh:mm:ss) & Žemaian & 52 & $2: 57: 47$ & $0: 05: 32$ \\
Recovery time & Arabian & 60 & $3: 12: 02$ & $0: 05: 24$ \\
(hh:mm:ss) & Žemaitukai & 52 & $0: 04: 41$ & $0: 00: 33$ \\
\hline
\end{tabular}

$\overline{* * *} p<0.001 ; n-$ total number of horses; M-mean; SE—standard error of the mean, $\mathrm{km} / \mathrm{h}$-kilometers per hour

It was found that of all blood biochemical parameters of the Arabian breed, Fe before competition most positively correlated with the speed of horse $(\mathrm{r}=0.675, p<0.01)$ and GGT ( $\mathrm{r}=0.600, p<0.01)$ after competition. Most negatively correlated were $\mathrm{Ca}, \mathrm{Mg}$, $\mathrm{TB}$, and $\mathrm{Cu}(\mathrm{r}=0.600-0.900, p<0.01)$ before competition; and Fe, CREA, TP, ALB, and GGT $(r=0.600-0.996, p<0.01)$ after competition (Figure 1$)$. The recovery time of Arabian horses was mainly positively related with blood urea and $\mathrm{Zn}(\mathrm{r}=0.600-0.800, p<0.01)$ and negatively correlated with $\mathrm{Mg}$, $\mathrm{Cu}$, and GGT in the blood ( $\mathrm{r}=0.500-0.975, p<0.01)$ before and after competition (Figure 1). 


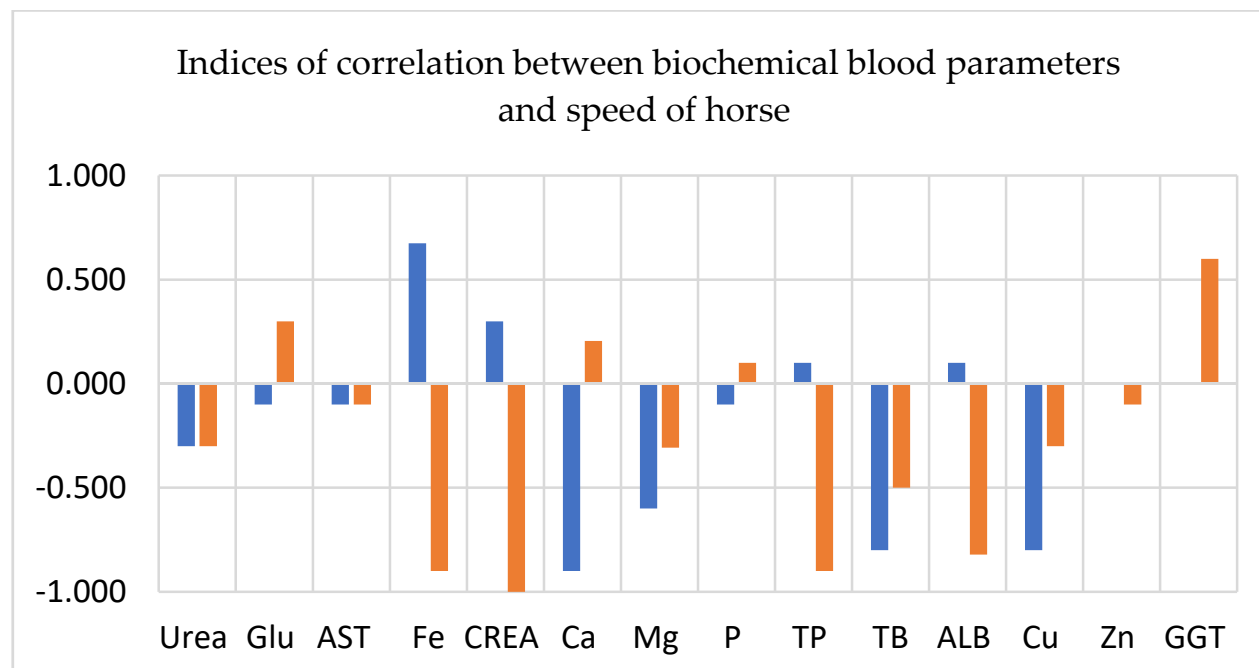

- Speed / Indices before competition $\square$ Speed / Indices after competition

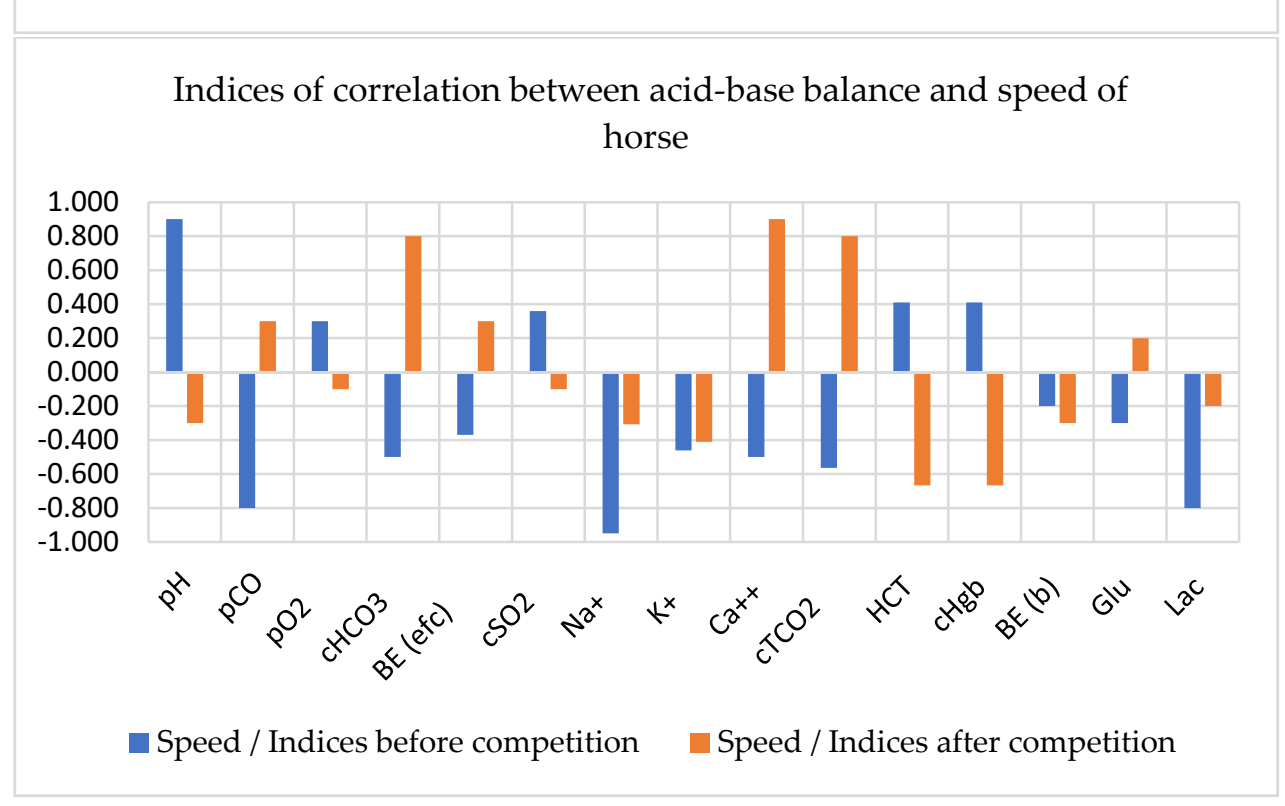

Figure 1. Correlations between blood indices and the speed of the Arabian horses. $\mathrm{pH}-$ hydrogen potential; $\mathrm{pCO}_{2}-$ partial carbon dioxide pressure; $\mathrm{pO}_{2}$ - partial oxygen pressure; $\mathrm{BE}$-base excess in the blood; $\mathrm{BE}$ (efc) —base excess in the extracellular fluid; $\mathrm{HCO}_{3}$ - bicarbonate; $\mathrm{CSO}_{2}$ - oxygen saturation; $\mathrm{tCO}_{2}$ - total carbon dioxide in the blood; $\mathrm{HCT}$ hematocrit; $\mathrm{Hgb}$ —hemoglobin concentration; $\mathrm{Glu}$ —glucose; $\mathrm{Na}^{+}$—-sodium; $\mathrm{K}^{+}$—potassium; $\mathrm{Ca}^{++}$-ionized calcium; Lac— lactate; Urea—serum urea; Glu—glucose; AST—aspartate aminotransferase; Fe—iron; CREA—creatinine; Ca—total calcium; $\mathrm{Mg}$ —-magnesium; $p$-phosphorus; TP—total protein; TB—total bilirubin; ALB—albumin; Cu—cuprum; Zn—zinc; GGT— gamma-glutamyl transferase.

Analysis of the correlations between the speed of the Arabian horses (Figure 1E) and the indicators of acid-base balance showed positive correlations with $\mathrm{pH}, \mathrm{pO}_{2}, \mathrm{CSO}_{2}, \mathrm{HCT}$, and $\mathrm{Hgb}(p<0.05)$ and negative correlations with $\mathrm{pCO}, \mathrm{BE}(\mathrm{efc}), \mathrm{Na}^{+}, \mathrm{K}^{+}, \mathrm{Ca}^{++}, \mathrm{tCO}_{2}, \mathrm{Glu}$, and Lac $(p<0.05)$ before competition. Post-race blood tests for $\mathrm{HCO}_{3}, \mathrm{Ca}^{++}$, and $\mathrm{tCO}_{2}$ showed positive correlations of these parameters with the speed of horse, whereas $\mathrm{pH}$, $\mathrm{Na}^{+}, \mathrm{K}^{+}, \mathrm{HCT}, \mathrm{Hgb}$, and BE (b) negatively correlated with the speed of horse $(p<0.05)$.

Based on the correlation analysis of biochemical parameters of the Žemaitukai horses (Figure 2), it can be concluded that $p$ before competition and TB after competition were mainly negatively related with the speed of horse $(p<0.01)$. It was also found that the 
recovery time of this breed (Figure 2) has a negative significant correlation with GGT before competition, and with $\mathrm{Mg}$ and $p$ after competition $(p<0.01)$.

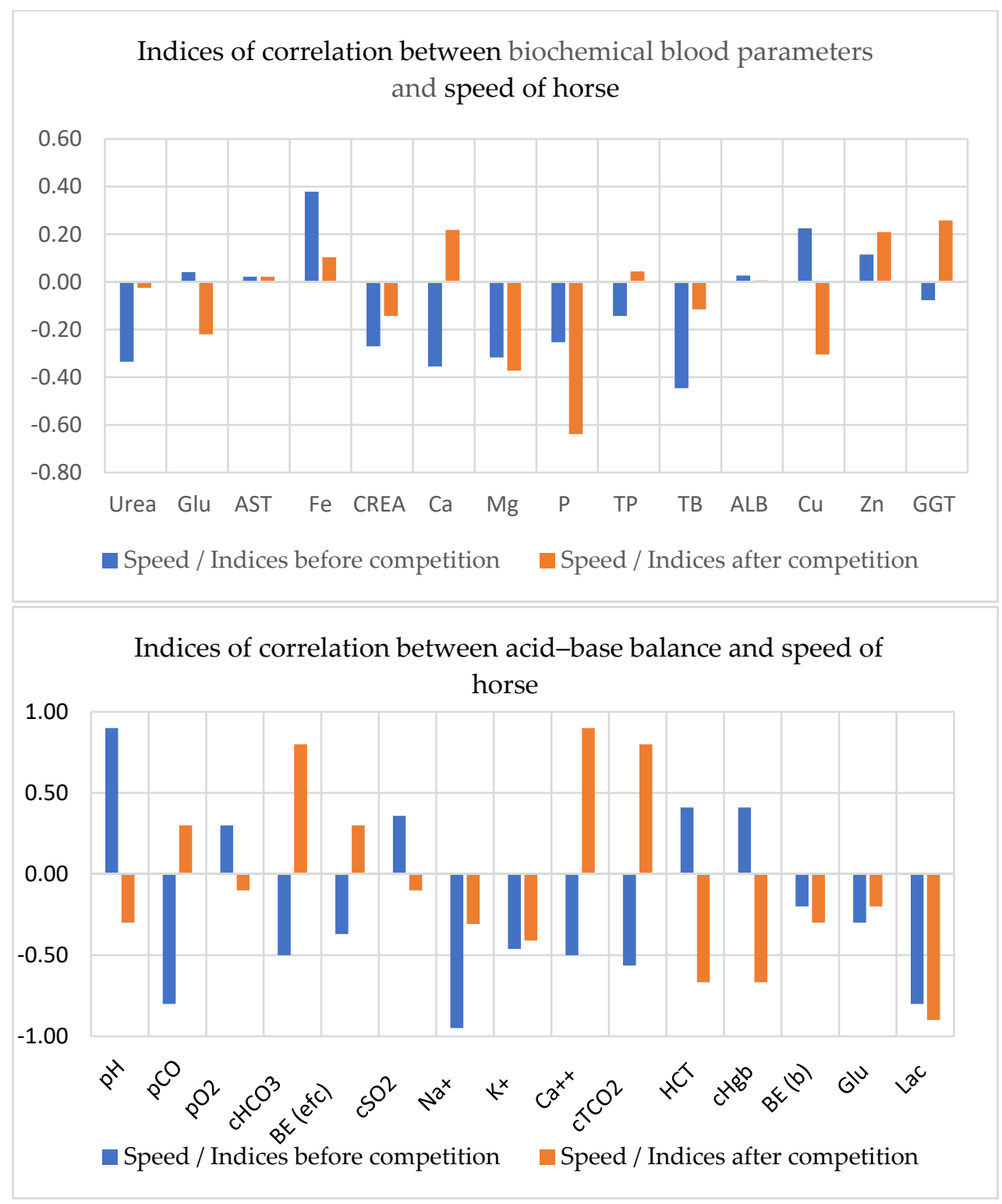

Figure 2. Correlations between blood indices and the speed of the Žemaitukai horses. $\mathrm{pH}-$ hydrogen potential; $\mathrm{pCO}_{2}-$ partial carbon dioxide pressure; $\mathrm{pO}_{2}$ - partial oxygen pressure; $\mathrm{BE}$-base excess in the blood; $\mathrm{BE}$ (efc) — base excess in the extracellular fluid; $\mathrm{HCO}_{3}$ - bicarbonate; $\mathrm{CSO}_{2}$ - oxygen saturation; $\mathrm{tCO}_{2}$ - total carbon dioxide in the blood; $\mathrm{HCT}$ hematocrit; $\mathrm{Hgb}$-hemoglobin concentration; Glu—glucose; $\mathrm{Na}^{+}$—-sodium; $\mathrm{K}^{+}$—potassium; $\mathrm{Ca}^{++}$-ionized calcium; Laclactate; Urea—serum urea; Glu—glucose; AST—aspartate aminotransferase; Fe-iron; CREA—creatinine; Ca—total calcium; Mg—magnesium; $p$ —-phosphorus; TP—total protein; TB—-total bilirubin; ALB—albumin; Cu—cuprum; Zn—zinc; GGT— gamma-glutamyl transferase.

The indicators of acid-base balance of the Žemaitukai breed showed the highest positive correlation of horse speed with blood $\mathrm{pH}$ before competition, and with $\mathrm{Ca}^{++}(\mathrm{r}=0.900$, $p<0.01), \mathrm{HCO}_{3}$, and $\mathrm{tCO}_{2}$ after competition $(\mathrm{r}=0.800, p<0.01)$. The highest negative correlations of horse speed were with $\mathrm{pCO}$ and Lac before competition $(\mathrm{r}=-0.800-0.802$, $p<0.01)$ and with HCT and Hgb after competition $(\mathrm{r}=-0.670-0.672, p<0.01)$ (Figure 2). 


\section{Discussion}

In the study, significant differences between the pre- and postrace blood parameters of the Žemaitukai and Arabian endurance horses were found. Pre-race blood samples showed lower hematocrit values; however, they still fell within the reference range [23]. In postrace blood testing, an increase of hematocrit was observed. An insignificant increase in hemoglobin was found in postrace blood samples. These findings were described in previous studies [24,25]. Splenic contraction induced by adrenergic stimulus and sweating, causing extensive body fluid losses, has been observed in the conditions of more prolonged exercise [26]. The study revealed relationships between breed and HTC, Hb change, and TP concentration. According to Fan et al. [27], increases in HTC percentage and TP concentration can be indicative of dehydration status occurring in result of the action of xanthine oxidase in free radical production, which in turn is determined by the permeability of muscle cell membrane. Dehydration is normally observed in all horses participating in endurance races. However, dehydration levels may vary. They are directly related to the sweat rate, which is determined by the amount and rate of physical work performed and by the environmental temperature and humidity [28]. Training and heat acclimatization can increase the sweat rate by 10 to 20 percent [29]. Decreased blood volume, high expenditure of energy, and muscular damage can indicate changes in equine biochemical profiles during long endurance racing [30]. Decreased blood volume first of all indicates an extensive loss of body fluid and electrolytes and low intake of fluid. During this study, a negative correlation between the CREA values and horse speed was established for both breeds after competition. Due to muscular metabolism, the final catabolite creatinine is developed, and the final catabolite of endogenous protein breakdown is urea [31]. An elevated concentration of urea can be observed in the horses after prolonged exercise. This was revealed by a study of horses competing in $121 \mathrm{~km}$ and $164 \mathrm{~km}$ endurance races [32]. This is consistent with the increase in postrace concentration of urea observed in our study. The postrace increase in creatinine concentration was also observed in the horses competing in the $160 \mathrm{~km}$ endurance races [33]. Another study revealed that a higher degree of dehydration due to intensified physical effort can result in increased levels of urea and creatinine after the $80 \mathrm{~km}$ races [34], implying a significant positive correlation between the above-mentioned parameters. The study showed that CREA levels were increased in both breeds after exercise; however, for the Žemaitukai horses, the rise of creatinine was higher, leading to significant decreases in the urea-CREA ratio. The mechanism for changes in serum creatinine following aerobic training could be related to the theoretical and empirical reports insisting that creatinine concentration is positively associated with body mass index, body fat, and fat distribution [35]. Before and after competition, higher levels of CREA were observed in the Arabian horses, probably as a result of the larger muscle mass [36], although the weights of breeds of horses were similar. A low body fat percentage and a large amount of muscle are of benefit to horses being considered to be elite level endurance racers. Creatinine and urea elevation may also result from a higher metabolic rate [37].

The serum iron concentration was significantly reduced in postrace Žemaitukai horses and increased in the Arabian horses. The ability to maintain prolonged submaximal exercise and the activity of iron-dependent oxidative enzymes is sufficiently closely related to tissue iron levels, which are a determining factor for endurance performance during prolonged submaximal exercise [38]. Lack of hemoglobin may significantly affect physical performance, as there will be a decrease in oxygen transport to exercising muscle. Decreases of hemoglobin levels and tissue iron content may have an adverse effect on performance [38]. Iron supplementation has been reported [39] to increase physical performance and motivation and improve efficient energy use in humans involved in various types of physical activities, whereas iron deficiency contributes to reduced aerobic capacity of muscle, and decreased tissue concentrations of nonheme iron can have detrimental effects because it functions as an enzyme cofactor [40]. Serum concentrations of the 
iron storage protein ferritin have been correlated with performance in nonanemic female marathon runners [41].

Exercise did not affect mineral requirements greatly, despite the possible increase in the request for minerals associated with the need for more energy to the muscles $(\mathrm{Ca}, \mathrm{Mg}$, and $p$ ) and production of saliva and sweat $\left(\mathrm{Na}^{+}\right)$[42]. The blood $\mathrm{K}^{+}$levels decreased after racing in both breeds. Similarly, another study found that the loss of potassium via sweat and renal fluid reabsorption through the kidneys were associated with potassium and hydrogen ion release [43]. Di Filippo et al. (2005) [42] also reported that the Arabian horses had a lower $\mathrm{K}^{+}$concentration after $60 \mathrm{~km}$ of endurance racing [44]. Lowered $\mathrm{K}^{+}$levels during exercise have a significant negative effect on a horse's performance [45]. Loss of potassium may result in fatigue, weakness, reduced intestinal motility, and paralytic bowel, and sometimes even lead to altered electrocardiographic traces [46].

In this study, a lactate increase after endurance exercise in the Arabian horses was observed. However, decreased blood lactate concentrations might occur due to poor glucose utilization by the metabolizing tissues [47]. Substitution in the metabolic preference for glucose over lipids was the mainstay of increase in the blood lactate levels. Besides, active exportation of lactate from muscles into the blood is possible [48]. Another study found a sudden upsurge of lactate concentration after $15 \mathrm{~min}$ of recovery [49]. The horses with high lactate concentrations showed better results than those with low lactate levels, indicating that other mechanisms may be involved in the regulation of blood lactate concentration [50]. Nevertheless, postrace blood lactate concentrations were higher than pre-race ones for all horses; however, they were elevated more in the Arabian horses than in the Žemaitukai breed, probably owing to the significantly higher anaerobic capacity in the Arabian horses. The postrace values of $\mathrm{pH}_{1} \mathrm{HCO}_{3}{ }^{-}, \mathrm{BE}$, and Hct in both horse breeds were higher than the pre-race ones. Increases in $\mathrm{pH}$ values of the horses can be related to the loss of chloride ions via sweat. Due to the body's need to restore the balance of negative charges, the loss of chlorine via sweat results in retention of the second most abundant ions in the organism, bicarbonate ions $\left(\mathrm{HCO}_{3}{ }^{-}\right)$[51]. In turn, the excess of $\mathrm{HCO}_{3}{ }^{-}$triggers hypochloremic metabolic alkalosis [45]. According to Johnson (1995), this alkalosis is an important clinical complication in exhaustion syndrome and in the cases of exertional rhabdomyolysis [52]. To maintain $\mathrm{pH}$ homeostasis, the body has three lines of response: chemical buffers, respiratory regulation, and renal regulation [43]. Due to changes in the blood $\mathrm{pH}$, respiratory compensation occurs almost immediately, altering the $\mathrm{pCO}_{2}$ [52]. Over a long run, regulation of the acid-base balance requires excretion of $\mathrm{H}^{+}$ions and retention of bicarbonate ions by the kidneys [53]. In line with these findings, the results show changes in postrace $\mathrm{pCO}_{2}$ and $\mathrm{pO}_{2}$. These findings indicated respiratory acidosis, which added to metabolic alteration, is called metabolic alkalosis with respiratory compensation. This respiratory modifications is common in sporting animals when faced with metabolic alkalosis [43], and is a reflection of the animals' organic health. Increased extraction of oxygen from the blood determines the reduction of venous oxygen content [54]. Under resting conditions, oxygen extraction ranges between $20 \%$ and $40 \%$. During exercise, approximately $70-80 \%$ of the oxygen delivered to the active muscles may be extracted. This demonstrates that there is a reserve of oxygen in the blood that can be utilized immediately to meet the needs of the contracting muscles at the onset of exercise. Increased extraction of oxygen from the blood is driven by the decreases in perivascular $\mathrm{PO}_{2}$, which in turn are driven by the reductions in cell $\mathrm{PO}_{2}$ [9]. The apparent breed difference in aerobic and anaerobic capacity may, in part, reflect breed variation in muscle fiber types and the muscle concentrations and activities of enzymes involved in glycolysis [55]. Excess body fat increases the energy requirements of weightbearing work, such as running, by increasing the energy requirements of exercise for any given intensity of work during a maximal oxygen consumption test [56]. This may be detrimental to running performance in that the running speed that can be sustained for a given duration is reduced [57], thereby increasing race time. 


\section{Conclusions}

This study showed that for the faster Arabian horse breed, recovering after racing took half the time taken by the local Žemaitukai breed. Based on hematocrit changes during exercise, the Arabian horses were found to have a higher sweat rate. Before and after competition, higher levels of creatinine were observed in the Arabian horses, probably as a result of having more muscle mass than Zemaitukai horses. Postrace blood lactate concentrations were higher for all horses; however, they were elevated more in the Arabian horses because of the greater muscle mass and higher activity level of the latter breed. Lower amounts of electrolytes and smaller changes during races showed that the Žemaitukai horses had a lower capacity for heat tolerance, suggesting that the Žemaitukai horses were less trained for endurance competition. Those differences between the two breeds might be based on different amounts of fat free body mass. Further studies are required to determine the inter-breed differences in muscle architecture and body composition.

Author Contributions: I.P., writing, planning and coordination of the whole study; V.J., statistical analysis, software development and algorithm development; J.A., design of the field experiment and data collection; R.G., assistance in handling manuscript data and advice on evaluating the results obtained; R.A., coordination of the study. The manuscript has been written by I.P. and revised by all co-authors. All authors have read and agreed to the published version of the manuscript.

Funding: This research received no external funding.

Institutional Review Board Statement: The study was conducted according to the guidelines of the Declaration of Helsinki, and ap-proved by Ethics Committee (The study approval number is PK016965, 2017.06.06).

Data Availability Statement: The data presented in this study are available within the article.

Conflicts of Interest: The authors declare no conflict of interest.

\section{References}

1. Fédération Equeste Internationale (FEI) Annual Report 2015. Available online: http://inside.fei.org/fei/about-fei/publications/ fei-annual-report/2015/ (accessed on 29 December 2020).

2. Williams, J.; Douglas, J.; Davies, E.; Bloom, F.; Castejon, C. Performance demands in the Endurance Rider. Comp. Exerc. Physiol. 2020, 1-20. [CrossRef]

3. Smith, C.A. Electrolyte imbalances and metabolic disturbances in endurance horses. Comp. Cont. Ed. Pract. Vet. 1985, 7, 575-582.

4. Rivero, J.L.; Ruz, M.C.; Serrano, A.L. Effects of a 3 month endurance training programme on skeletal muscle histochemistry in Andalusian, Arabian and Anglo-Arabian horses. Equine Vet. J. 1995, 27, 51-59. [CrossRef]

5. Cosgrove, E.J.; Sadeghi, R.; Schlamp, F.; Holl, H.M.; Moradi-Shahrbabak, M.; Miraei-Ashtiani, S.R.; Abdalla, S.; Shykind, B.; Troedsson, M.; Stefaniuk-Szmukier, M.; et al. Genome Diversity and the Origin of the Arabian Horse. Sci. Rep. 2020, 10, 9702. [CrossRef]

6. United States Equestrian Federation. Chapter AR. In Arabian, Half-Arabian and AngloArabian Division Rule Book, Rule AR-102; United States Equestrian Federation: Lexington, KY, USA, 2008.

7. López-Rivero, J.L.; Aguera, E.; Monterde, J.G.; Vivo, J.; Rodriguez-Barbudo, M.V. Skeletal muscle fiber size in untrained and endurance trained horses. Am. J. Vet. Res. 1992, 53, 847-850.

8. López-Rivero, J.L.; Aguera, E.; Monterde, J.G.; Rodriguez-Barbudo, M.V.; Miro, F. Comparative study of muscle fiber type composition in the middle gluteal muscle of Andalusian, Thoroughbred and Arabian horses. J. Equine Vet. Sci. 1989, 9, 337-340. [CrossRef]

9. Prince, A.; Geor, R.; Harris, P.; Hoekstra, K.; Gardner, S.; Hudson, C.; Pagan, J. Comparison of the metabolic responses of trained Arabians and Thoroughbreds during high- and low-intensity exercise. Equine Vet. J. 2002, 34, 95-99. [CrossRef] [PubMed]

10. Knorr, F. A history of the Arabian horse and its influence on modern breeds. Am. Breed. Mag. 1912, 3, 174-180. [CrossRef]

11. Zechner, J.; Sölkner, B.I.; Druml, T.; Baumung, R.; Achmann, R.; Marti, E.; Habe, F.; Brem, G. Analysis of diversity and population structure in the Lipizzan horse breed based on pedigree information. Livestock Prod. Sci. 2002, 77, 137-146. [CrossRef]

12. Macijauskienè, V. Šveistienẻ Žemaituku ir stambiuju žemaituku arkliu eksterjero bei augimo spartos palyginimas. Vet. Zootech. 2002, 19, 76-81.

13. Gle $\beta$, J.K. Kleinpferde; VEB Deutschen Landwirtschaft Sverlag: Berlin, Germany, 1989.

14. Poskiene, I.; Juozaitienè, V.; Gruodytè, R.; Antanaitis, R. The effect of $60 \mathrm{~km}$ endurance exercise on serum electrolytes and acid-base balance in the Žemaitukai horses. Acta Vet. Brno 2020, 89, 125-131. [CrossRef] 
15. Abbiss, C.R.; Laursen, P.B. Describing and understanding pacing strategies during athletic competition. Sports Med. 2008, 38, 239-252. [CrossRef]

16. Padilla, S.; Mujika, I.; Orbananos, J. Exercise intensity during competition time trials in professional road cycling. Med. Sci. Sports Exerc. 2000, 32, 850-856. [CrossRef] [PubMed]

17. Melanson, E.L.; MacLean, P.S.; Hill, J.O. Exercise improves fat metabolism in muscle but does not increase 24-h fat oxidation. Exerc. Sport Sci. Rev. 2009, 37, 93-101. [CrossRef] [PubMed]

18. Ropka-Molik, K.; Stefaniuk-Szmukier, M.; Musiał, A.D.; Velie, B.D. The Genetics of Racing Performance in Arabian Horses. Int. J. Genom. 2019, 2019. [CrossRef]

19. Wright, M.E.; Croser, E.L.; Raidal, S.; Baral, R.M.; Robinson, W.; Lievaart, J.; Freeman, K.P. Biological variation of routine haematology and biochemistry measurands in the horse. Equine Vet. J. 2019, 51, 384-390. [CrossRef]

20. Sediame, S.; Zerah-Lancner, F.; d'Ortho, M.P.; Adnot, S.; Harf, A. Accuracy of the i-STAT bedside blood gas analyser. Eur. Respir. J. 1999, 14, 214-217. [CrossRef] [PubMed]

21. Whitingf, J. The Exhausted Horse. Current Therapy in Equine Medicine, 6th ed.; Saunders Elsevier: St. Louis, MO, USA, 2009.

22. Winnicka, A. The Reference Values of Basic Laboratory Analysis in Veterinary Medicine, 4th ed.; SGGW Publishers: Warsaw, Poland, 2008.

23. Al-Qudah, K.M.; Al-Majali, A.M. Status of biochemical and antioxidant variables in horses before and after long distance race. Rev. Med. Vet. 2006, 6, 307-312.

24. McKeever, K.H.; Schurg, W.A.; Jarrett, S.H.; Convertino, V.A. Exercise training-induced hypervolemia in the horse. Med. Sci. Sports Exerc. 1987, 19, 21-27. [CrossRef]

25. Waller, A.P.; Heigenhauser, G.J.; Geor, R.J.; Spriet, L.L.; Lindinger, M.I. Fluid and electrolyte supplementation after prolonged moderate-intensity exercise enhances muscle glycogen resynthesis in Standardbred horses. J. Appl. Physiol. 2009, 106, 91-100. [CrossRef] [PubMed]

26. Fan, Y.K.; Hsu, J.C.; Peh, H.C.; Tsang, C.L.; Cheng, S.P.; Chiu, S.C.; Ju, J.C. The effects of endurance training on the hemogram of the horse. Asian Aust. J. Anim. Sci. 2002, 15, 1348-1353. [CrossRef]

27. De Waal, A.; Potgieter, F.J. Evaluation of an electronic device used as a quick screening method to detect changes in the red cell content of the blood in horses participating in endurance trail rides. Vet. Res. Commun. 1991, 15, 309. [CrossRef] [PubMed]

28. Gisolfi, C.V. Temperature Regulation during Exercise: An Overview; Department of Exercise Science, The University of Iowa: Iowa City, IA, USA, 1984.

29. Larsson, J.; Pilborg, P.H.; Johansen, M.; Christophersen, M.T.; Holte, A.; Roepstorff, L.; Olsen, L.H.; Harrison, A.P. Physiological Parameters of Endurance Horses Pre-Compared to Post-Race, Correlated with Performance: A Two Race Study from Scandinavia. ISRN Vet. Sci. 2013, 684353. [CrossRef] [PubMed]

30. Carlotti, A.P.; Bohn, D.; Matsuno, A.K.; Pasti, D.M.; Gowrishankar, M.; Halperin, M.L. Indicators of lean body mass catabolism: Emphasis on the creatinine excretion rate. QJM Int. J. Med. 2008, 101, 197-205. [CrossRef] [PubMed]

31. Castejon, F.; Trigo, P.; Muñoz, A.; Riber, C. Uric acid responses to endurance racing and relationships with performance, plasma biochemistry and metabolic alterations. Equine Vet. J. 2006, 36, 70-73. [CrossRef] [PubMed]

32. Klobučar, K.; Vrbanac, Z.; Gotić, J.; Bojanic, K.; Bureš, T.; Brkljača, N. Changes in biochemical parameters in horses during 40 km and $80 \mathrm{~km}$ endurance races. Acta Vet. Scand. 2019, 69, 73-87. [CrossRef]

33. Baxmann, A.C.; Ahmed, M.S.; Marques, N.C.; Menon, V.B.; Pereira, A.B.; Kirsztajn, G.M.; Heilberg, I.P. Influence of muscle mass and physical activity on serum and urinary creatinine and serum cystatin C. Clin. J. Am. Soc. Nephrol. 2008, 3, 348-354. [CrossRef]

34. Gerchman, F.; Tong, J.; Utzschneider, K.M.; Zraika, S.; Udayasankar, J.; McNeely, M.J.; Carr, D.B.; Leonetti, D.L.; Young, B.A.; de Boer, I.H.; et al. Body Mass Index Is Associated with Increased Creatinine Clearance by a Mechanism Independent of Body Fat Distribution. J. Clin. Endocrinol. Metab. 2009, 94, 3781-3788. [CrossRef]

35. Hodgson, D.R.; Davis, R.E.; McConaghy, F.F. Thermoregulation in the horse in response to exercise. Br. Vet. J. 1994, 3, $219-235$. [CrossRef]

36. Stockham, S.L.; Scott, M.A. Fundamentals of Veterinary Clinical Pathology, 1st ed.; Iowa State Press: Ames, IA, USA, 2002.

37. Pearson, A.; Dijkman, J.T. Nutritional implications of work in draught animals. Proc. Nutr. Soc. 1994, 53, 169-179. [CrossRef]

38. McClung, J.P.; Karl, J.P.; Cable, S.J.; Williams, K.W.; Nindl, B.C.; Young, A.J.; Lieberman, H.R. Randomized, double-blind, placebo-controlled trial of iron supplementation in female soldiers during military training: Effects on iron status, physical performance, and mood. Am. J. Clin. Nutr. 2009, 90, 124-131. [CrossRef] [PubMed]

39. Beard, J.; Tobin, B. Iron status and exercise. Am. J. Clin. Nutr. 2000, 72, 594S-597S. [CrossRef]

40. Arrese, A.L.; Izquierdo, D.M.; Galindo, J.R.S. Physiological measures associated with marathon running performance in highlevel male and female homogeneous groups. Int. J. Sports Med. 2006, 27, 289-295. [CrossRef] [PubMed]

41. Mccpnaghy, F. Thermoregulation. The Athletic Horse: Principles and Practice of Equine Sports Medicine; Hodgson, D.R., Rose, R.J., Eds.; W.B. Saunders: Philadelphia, PA, USA, 1994.

42. Di Filippo, P.M.; Marcos, D.M.; Tinoco, L.; Salles, P.; Soares, G. Gender Differences-Induced Changes in Serum Hematologic and Biochemical Variables in Mangalarga Marchador Horses After a Marcha Gait Competition. J. Equine Vet. Sci. 2016, 43, 18-22. [CrossRef]

43. Snow, D.H.; Kerr, M.G.; Nimmo, M.A.; Abbott, E.M. Alterations in blood, sweat, urine and muscle composition during prolonged exercise in the horse. Vet. Rec. 1982, 17, 377-384. [CrossRef] 
44. Day, T.K. Blood gas analysis. Vet. Clin. N. Am. Small Anim. Pract. 2002, 32, 1031-1048. [CrossRef]

45. Lawan, A.; Noraniza, M.; Rasedee, A.; Bashir, A. Effects of Race Distance on Physical, Hematological and Biochemical Parameters of Endurance Horses. Am. J. Anim. Vet. Sci. 2010, 5, 244-248.

46. Hyyppä, S.; Pösö, A.R. Fluid, electrolyte, and acid-base responses to exercise in racehorses. Vet. Clin. N. Am. Equine Pract. 1998, 14, 121-136. [CrossRef]

47. Campbell, E.H. Lactate-driven equine conditioning programmes. Vet. J. 2011, 190, 199-207. [CrossRef] [PubMed]

48. Lawan, A.; Mohd, A.N.; Abdullah, R.; Ahmad, B. Effect of Age and Performance on Physical, Hematological, and Biochemical Parameters in Endurance Horses. J. Equine Vet. Sci. 2013, 33, 415-420.

49. Johnson, P.J. Electrolyte and acid-base disturbances in the horse. Vet. Clin. N. Am. Equine Pract. 1995, 11, 491-514. [CrossRef]

50. Linhares, J.; Di Filippo, P.; Bogossian, P.; Guerra, R.; Bustamante, S.; Carvalho, C.; Ferreira, F. Physical exercise on serum electrolytes and acid base balance in Mangalarga Marchador horses submitted to cavalcade of 4, 8 and 20km. Ciência Rural. 2017, 47, 10. [CrossRef]

51. Robinson, N.E. Homeostase ácido-básica. In Tratado de Fisiologia Veterinária; Guanabara Koogan: Rio de Janeiro, Brazil, 2004.

52. Fettman, M.J. Fluid and Electrolyte Metabolism. Veterinary Hematology and Clinical Chemistry; Thrall, M.A., Ed.; Lippincott Williams \& Wilkins: Philadelphia, PA, USA, 2004.

53. Hogan, M.C.; Willford, D.C.; Keipert, P.E.; Faithfull, N.S.; Wagner, P.D. Increased plasma $\mathrm{O}_{2}$ solubility improves $\mathrm{O}_{2}$ uptake of in situ dog muscle working maximally. J. Appl. Physiol. 1992, 73, 2470-2475. [CrossRef] [PubMed]

54. Granger, H.J.; Borders, J.L.; Meininger, G.A.; Goodman, A.H.; Barnes, G.E. Microcirculatory control systems. Physiol. Pharmacol. Microcirc. 1983, 1, 209-235.

55. Kearns, C.F.; McKeever, K.H.; Abe, T. Overview of Horse Body Composition and Muscle Architecture: Implications for Performance. Vet. J. 2002, 164, 224-234. [CrossRef]

56. Cureton, K.J. Effects of Experimental Alterations in Excess Weight on Physiological Responses to Exercise and Physical Performance. In Body Composition and Physical Performance; National Academy Press: Washington, DC, USA, 1992; pp. 71-88.

57. Ghosh, A.K. Anaerobic threshold: Its concept and role in endurance sport. Malays J. Med. Sci. 2004, 11, 24-36. 